\title{
Renata Podgórzańska*
}

\section{UDZIAL POLSKI W OPERACJACH POKOJOWYCH UNII EUROPEJSKIEJ. DYLEMATY I WYZWANIA}

\section{Wprowadzenie}

Niestabilność otoczenia zewnętrznego wymaga od Unii Europejskiej aktywnego włączania się w proces niwelowania zagrożeń, przywracania pokoju i umacniania bezpieczeństwa, zarówno państw sąsiadujących z UE, jak i poza Unią. Pretendując do roli „globalnego gracza” Unia rozbudowuje arsenał instrumentów służących kreowaniu aktywnej polityki zagranicznej i bezpieczeństwa. Koncentruje się nie tylko na wzmacnianiu własnego bezpieczeństwa, lecz intensyfikuje wysiłki wobec zewnętrznego otoczenia, rozwijając cywilne i wojskowe zdolności zapobiegania konfliktom i zarządzania kryzysowego (od strategii zapobiegawczych po odnowę i odbudowę po kryzysie). Różnorodność zagrożeń, z którymi zmaga się Europa wymaga aktywności, solidarności i spójności działaniaª

Jedną ze stosowanych form reagowania UE na zagrożenia dla pokoju i bezpieczeństwa $\mathrm{w}$ państwach i regionach konfliktogennych, realizowaną $\mathrm{w}$ ramach Wspólnej Polityki Bezpieczeństwa i Obrony, są obejmujące zdolności wojskowe i cywilne operacje pokojowe ${ }^{2}$. Niezależnie od wątpliwości co do skuteczności tego rodzaju działań, przez dziesięciolecia pozostawały one dla społeczności

* dr hab. Renata Podgórzańska, Instytut Politologii i Europeistyki US, e-mail: renata.podgorzanska@wp.pl.

1 Bezpieczna Europa w lepszym świecie. Europejska Strategia Bezpieczeństwa, http://consilium.europa.eu/uedocs/cmsUpload/031208ESSIIPL.pdf (22.10.2014).

2 Z uwagi na wiele zaangażowanych podmiotów, skalę i charakter prowadzonych działań, a także ich wieloaspektowość, nie udało się dotychczas wypracować spójnej, jednolitej definicji operacji pokojowych. Zob. D. Kozerawski, Kontyngenty Wojska Polskiego w międzynarodowych operacjach pokojowych w latach 1973-1999. Konflikty - interwencja - bezpieczeństwo, Toruń 2012, s. 25-42. 
międzynarodowej jednym z instrumentów reagowania. Sukcesywnie, acz nie bez kontestacji ze strony części państw członkowskich, w tę formę odpowiedzialności za stabilizację środowiska międzynarodowego włączała się UE. Decyzja państw członkowskich o wyposażeniu Unii w środki i mechanizmy umożliwiające skuteczne działanie poza jej granicami wynikała z uznania, że poprzez podejmowanie operacji pokojowych będzie zdolna wywierać wpływ na kształt stosunków międzynarodowych oraz oddziaływać na poziom bezpieczeństwa w bliższym i dalszym sąsiedztwie ${ }^{3}$. Przy czym podkreślić należy, że tempo rozwoju zdolności UE do autonomizacji w zakresie prowadzenia operacji pokojowych, a tym samym skala, charakter i co ważne skuteczność unijnej aktywności przez lata uzależniona była zarówno od zdolności finansowych i organizacyjnych, jak i politycznej woli państw członkowskich do jej usamodzielnienia w dziedzinie bezpieczeństwa. Przez lata trwających debat wypracowano założenia zaangażowania UE w operacje pokojowe, które pozwoliły na angażowanie się w działania związane z bezpieczeństwem, posługując się tym właśnie instrumentem ${ }^{4}$.

Współcześnie, Wspólna Polityka Bezpieczeństwa i Obrony stanowiąc integralną część Wspólnej Polityki Zagranicznej i Bezpieczeństwa umożliwia UE pełnienie istotnej roli w operacjach pokojowych. Wdrożone mechanizmy i posiadane zasoby zapewniają jej zdolność operacyjną opartą na środkach cywilnych i wojskowych ${ }^{5}$.

Nie jest przedmiotem analizy egzegeza rozwoju polityki UE w obszarze bezpieczeństwa i obrony. Nie jest również zamiarem autorki eksplanacja stanowiska Polski wobec autonomizacji UE w zakresie bezpieczeństwa ${ }^{6}$. Celem artykułu jest analiza motywów i skali zaangażowania Polski w operacje pokojowe Unii Europejskiej z perspektywy polityki zagranicznej po 1989 roku. Analiza powyższego zagadnienia wymaga szerszego spojrzenia, uwzględniającego

3 Zob. A. Ciupiński, Wspólna Polityka Bezpieczeństwa i Obrony Unii Europejskiej. Geneza. Rozwój. Funkcjonowanie, Warszawa 2013; R. Zięba, Wspólna Polityka Zagraniczna i Bezpieczeństwa Unii Europejskiej, Warszawa 2005; Ł. Kulesa, Operacje Unii Europejskiej w ramach europejskiej polityki bezpieczeństwa i obrony, Biuletyn PISM 2004, nr 42.

4 R. Zięba, Unia Europejska, w: Międzynarodowe stosunki polityczne, red. M. Pietraś, Lublin 2006, s. 127-130.

5 Zob. J. Wójtowicz, Specyfika Wspólnej Polityki Zagranicznej i Bezpieczeństwa w świetle postanowień Traktatu z Lizbony - instrumenty i ramy prawno-instytucjonalne, „Studia i Analizy Europejskie" 2011, nr 2, s. 15-22.

6 Zob. J. Czaputowicz, Polityka bezpieczeństwa Polski - między samodzielnościa a europeizacja, „e-Politikon”, nr 4, s. 24-41; T. Łoś-Nowak, Wspólna Polityka Zagraniczna i Bezpieczeństwa Unii Europejskiej z perspektywy Polski, „Przegląd Europejski” 2005, nr 1; R. Zięba, Polska we Wspólnej Polityce Bezpieczeństwa i Obrony Unii Europejskiej, „Polityka i Społeczeństwo" 2012, nr 10, s. 160-169. 
zarówno proces redefinicji założeń realizowanej po 1989 roku polskiej polityki zagranicznej, jak i przeobrażenia środowiska międzynarodowego oraz modyfikację charakteru samych operacji pokojowych, ich funkcji i charakteru, a przede wszystkim strategii i zdolności UE w tym zakresie. Przyjęta konstrukcja artykułu nie pozwala na wieloaspektową analizę, a jedynie na skoncentrowanie się na wybranych kwestiach, a mianowicie motywach i dylematach zaangażowania Polski w operacje pokojowe UE.

\section{Zaangażowanie Polski w operacje pokojowe z perspektywy polityki zagranicznej Polski po 1989 roku}

Jedynym z istotnych fragmentów realizowanej po 1989 roku polityki zagranicznej było zaangażowanie Polski w działania społeczności międzynarodowej na rzecz umacniania bezpieczeństwa w państwach i regionach konfliktogennych. Aktywność ta przybiera różnorodną postać od inicjatyw i aktywności dyplomatycznej, po bezpośredni udział w różnych typach operacji i misjach zarządzania kryzysowego.

Uzasadnienie zaangażowania w operacje pokojowe znajdziemy w dokumentach programowych polskiej polityki zagranicznej oraz polityki bezpieczeństwa. Pierwotne znaczenie mają kolejno przyjmowane po 1989 roku dokumenty o charakterze strategicznym (1990, 1992, 2000, 2003, 2007), w tym przyjęta w listopadzie 2014 roku Strategia bezpieczeństwa narodowego Rzeczypospolitej Polskiej ${ }^{7}$. Znajduje to również potwierdzenie w dokumencie precyzującym zasady angażowania się Polski poza granicami kraju - Strategii udziału Sił Zbrojnych Rzeczypospolitej Polskiej w operacjach międzynarodowych ${ }^{8}$.

Systematycznie również wola partycypacji w działaniach społeczności międzynarodowej znajdowała potwierdzenie w sejmowych wystąpieniach ministrów spraw zagranicznych, definiujących założenia polityki zagranicznej ${ }^{9}$. Sukcesywnie realizując przyjęte u progu transformacji priorytety $\mathrm{w}$ polityce

7 Por. Uchwała Komitetu Obrony Kraju z 21.02.1990 r. w sprawie doktryny obronnej Rzeczypospolitej Polskiej, MP 1990, nr 9, poz. 66; Polityka bezpieczeństwa i strategia obronna Rzeczypospolitej Polskiej, Warszawa 1992; Strategia obronności Rzeczypospolitej Polskiej, Warszawa 2000; Strategia bezpieczeństwa narodowego RP, Warszawa 2003; Strategia bezpieczeństwa narodowego Rzeczypospolitej Polskiej, Warszawa 2007; Strategia bezpieczeństwa narodowego Rzeczypospolitej Polskiej, Warszawa 2014.

$8 \quad$ Strategia udzialu Sił Zbrojnych Rzeczypospolitej Polskiej w operacjach międzynarodowych, http://www.bbn.gov.pl/portal/pl/475/2827/Strategia_udzialu_Sil_Zbrojnych_RP_w_operacjach_miedzynarodowych.html (22.10.2014).

9 Zob. R. Stemplowski, Wprowadzenie do analizy polityki zagranicznej, Warszawa 2007. 
zagranicznej potwierdzano gotowość udziału w działaniach społeczności międzynarodowej. Wola partycypacji w operacjach pokojowych została potwierdzona również w dokumencie Priorytety polskiej polityki zagranicznej na lata 2012-2016 ${ }^{10}$.

Zaangażowanie Polski na rzecz zapewnienia bezpieczeństwa i stabilizacji w państwach i regionach konfliktowych należy analizować przez pryzmat sformułowanych celów i priorytetów polityki zagranicznej. Polska od lat konsekwentnie wykorzystuje udział w operacjach pokojowych jako instrument realizacji polityki zagranicznej. Uczestnictwo w operacjach pokojowych, niezależnie od dyskusji na temat jego skali, charakteru, geograficznych kierunków aktywności traktowane jest jako wsparcie realizacji podstawowych założeń polityki zagranicznej ${ }^{11}$. Polskie uczestnictwo w inicjatywach podejmowanych przez społeczność międzynarodową miało z założenia wspierać dążenia do osiągnięcia celów polityki zagranicznej, w tym umacniać relacje z krajami zachodnimi, budować i wzmacniać szansę na akcesję do struktur współpracy euroatlantyckiej, a w przyszłości - rolę i znaczenie Polski w tych strukturach. Z czasem weryfikując założenia obecności w operacjach pokojowych zwrócono uwagę na potrzebę korelacji charakteru uczestnictwa z wymogami racji stanu. Równie istotne były możliwości finansowe i organizacyjne, w konsekwencji których zwyciężyło „selektywne podejście” do udziału w operacjach pokojowych ${ }^{12}$.

Nowy etap polskiego zaangażowania $\mathrm{w}$ misjach pokojowych wyznaczało uzyskanie członkostwa w NATO i zintensyfikowanie działań na rzecz akcesji do UE. Należy jednak pamiętać o sceptycyzmie jaki towarzyszył Polsce w momencie zainicjowania procesu tworzenia europejskiej polityki bezpieczeństwa, w szczególności zastrzeżeń do koncepcji geograficznego ukierunkowania użycia sił europejskich, rodzaju sytuacji determinujących konieczność ich użycia, sposobu prowadzenia operacji militarnych ${ }^{13}$.

Ewolucję udziału Polski w operacjach pokojowych potwierdza przytoczona Strategia udziału Sił Zbrojnych Rzeczypospolitej Polskiej w operacjach międzynarodowych. Konsekwentnie akcentuje się, że operacje pokojowe są nie tylko

$10 \quad$ Priorytety polskiej polityki zagranicznej 2012-2016, Warszawa 2012.

11 K. Pawłowski, Misje pokojowe i operacje stabilizacyjne Sit Zbrojnych Rzeczypospolitej Polskiej na poczatku XXI wieku: przesłanki i głosy krytyczne, http://www.pan-ol.lublin.pl/wydawnictwa/TPol5/Pawlowski.pdf (12.02.2015).

12 A. Drzewicki, Strategia udziatu Sił Zbrojnych Rzeczypospolitej Polskiej w operacjach międzynarodowych. Aspekty polityczne i wojskowe, „Rocznik Bezpieczeństwa Międzynarodowego" 2011, vol. 5, s. 181.

13 B. Balcerowicz, Aktywność Polski w dziedzinie bezpieczeństwa euroatlantyckiego, w: Polityka zagraniczna Polski po wstapieniu do NATO i Unii europejskiej, red. S. Bieleń, Warszawa 2010, s. 133. 
formą działania na rzecz zapewnienia Polsce określonego poziomu bezpieczeństwa, ale również sposobem realizacji jego głównych interesów, związanych z możliwością bezpośredniego oddziaływania na kształt budowanych systemów międzynarodowego bezpieczeństwa oraz wzmacniających pozycję Polski na arenie międzynarodowej jako aktywnego uczestnika i kreatora procesu umacniania światowej stabilności ${ }^{14}$. Przywołana Strategia priorytetowe znaczenie, z punktu widzenia polskiej racji stanu, przyznaje operacjom NATO i UE ${ }^{15}$.

Konkludując tę część wywodu, należy podkreślić, że właściwością polityki zagranicznej po 1989 roku było postrzeganie zaangażowania w operacjach pokojowych przez pryzmat zdefiniowanych interesów narodowych. O skali zaangażowania Polski decydowały jednak nie tylko zdefiniowane priorytety w polityce zagranicznej, ale również zdolności i możliwości partycypowania w przedsięwzięciach społeczności międzynarodowej.

\section{Udział w operacjach pokojowych UE - skala i charakter zaangażowania}

Przez lata fundamentem zaangażowania Polski w działania społeczności międzynarodowej na rzecz bezpieczeństwa i stabilizacji był udział w działaniach inicjowanych i prowadzonych przez ONZ. Z czasem Polska włączała się w przedsięwzięcia sygnowane przez inne podmioty, uzależniając skalę i charakter polskiej obecności od zdefiniowanych interesów, a także od zdolności i możliwości jakimi w danym czasie dysponowano. Ewolucja zaangażowania Polski w operacjach pokojowych oznaczała przemodelowanie udziału w podejmowanych przez społeczność międzynarodową przedsięwzięciach i stopniową rezygnację z działań prowadzonych przez ONZ na rzecz szerszego zaangażowania w inicjatywach NATO, a następnie UE. Nie rezygnując z atlantyckiego charakteru własnej polityki bezpieczeństwa, Polska postrzegała aktywność UE dotyczącą bezpieczeństwa jako uzupełnienie tego pierwszego. Podejmując decyzje o wsparciu unijnych działań, Polska przyłączyła się zarówno do procesu tworzenia zdolności militarnych UE, jak i zdolności cywilnych na potrzeby prowadzenia operacji pokojowych. Rewidując swoją postawę starano się potwierdzić wiarygodność Polski jako europejskiego sojusznika, który po latach negowania sensu budowania autonomicznych wobec NATO zdolności UE w zakresie bezpieczeństwa decyduje

14 A. Drzewicki, Strategia..., s. 180.

15 Strategia udziału Sił Zbrojnych Rzeczypospolitej Polskiej w operacjach międzynarodowych, http://www.bbn.gov.pl/portal/pl/475/2827/Strategia_udzialu_Sil_Zbrojnych_RP_w_operacjach_miedzynarodowych.html (22.02.2015). 
aktywniej włączać się w europejskie przedsięwzięcia. Ponadto za rewizją stanowiska przemawiała chęć modyfikacji obrazu Polski - jako państwa, które z integracji czerpie korzyści, głównie ekonomiczne, zaś lekceważy inne płaszczyzny procesu $^{16}$.

Unia Europejska, przyjmując na siebie odpowiedzialność za utrzymanie stabilności w Europie oraz „bezpośrednim sąsiedztwie Europy”, od 2003 roku zaczęła prowadzić operacje pokojowe systematycznie rozwijając swoje zdolności, zarówno związane $\mathrm{z}$ autonomicznym prowadzeniem operacji pokojowych, jak i przy współpracy z innymi podmiotami i przy wykorzystaniu ich zasobów. Za Andrzejem Ciupińskim, prowadzone operacje wojskowe podzielić można według kryterium geograficznego oraz kryterium systemowego (operacje prowadzone samodzielnie oraz operacje prowadzone w formule Berlin plus, czyli przy współpracy i z wykorzystaniem środków NATO) ${ }^{17}$. Przez lata UE z powodzeniem realizowała również działania w ramach operacji cywilnych.

Pierwszą operacją wojskową UE była operacja Concordia realizowana w Byłej Jugosłowiańskiej Republice Macedonii (FYROM), a zarazem była to pierwsza unijna operacja, w której uczestniczyła Polska. Celem misji było ustabilizowanie sytuacji, niedopuszczenie do konfliktu z mniejszością albańską oraz ustanowienie pokojowego, demokratycznego i prężnie działającego państwa. Istotnym jej elementem była realizacja postanowień umowy ramowej z Ochrydy, której kluczowymi założeniami było przywrócenie stabilności, ochrona niepodległości i integralności terytorialnej FYROM oraz utrzymanie wielonarodowego charakteru państwa, a także przerwanie wrogości i przemocy ${ }^{18}$. Operacja zakończyła się w grudniu 2003 roku $^{19}$; zastąpiono ją policyjną operacją UE Proxima ${ }^{20}$. Polski kontyngent podjął działania w ramach operacji wojskowej „Concordia” od 1 kwietnia 2003 roku $^{21}$. Polska była jednym z 14 państw spoza UE, które zdecy-

16 R. Zięba, Z Waszyngtonem czy Bruksela - dylemat polskiej polityki bezpieczeństwa, w: Unia Europejska i Polska wobec dylematów integracyjnych na początku XXI wieku, red. M. Stolarczyk, Toruń 2006, s. 407.

17 A. Ciupiński, Wspólna..., s. 228.

18 R. Woźnica, Rola Unii Europejskiej w realizacji postanowień porozumienia ochrydzkiego dotyczacego policji, w: Tożsamość narodowa w społeczeństwie multietnicznym, red. M. Kawka, I. Stawowy-Kawka, Kraków 2008, s. 278-279.

19 Wspólne Działanie Rady 2003/681/WPZiB z 29.09.2003 r. w sprawie Misji Policyjnej Unii Europejskiej w Byłej Jugosłowiańskiej Republice Macedonii (EUPOL „Proxima”), Dz. Urz. UE L. 249/66.

20 E. Posel-Częścik, Wspótpraca NATO i Unii Europejskiej $w$ dziedzinie opanowywania kryzysów, Biuletyn PISM 2004, nr 39, s. 2.

21 Postanowienie Prezydenta Rzeczypospolitej Polskiej z 28.03.2003 r. o użyciu Polskiego Kontyngentu Wojskowego w operacji wojskowej Unii Europejskiej w Byłej Jugosłowiańskiej 
dowały wesprzeć unijne działania. Wprawdzie pod względem liczebności polski kontyngent był nieliczny (17 żołnierzy) jednakże zaangażowanie Polski należy rozpatrywać przez pryzmat państwa, które usiłowało potwierdzić swoje przywiązanie do europejskich wartości.

W latach 90. XX wieku społeczność międzynarodowa zaangażowana była w utrzymanie bezpieczeństwa i umacnianie pokoju w Bośni i Hercegowinie. Polska systematycznie włączała się w działania podejmowane przez organizacje międzynarodowe, w tym w inicjatywy podejmowane przez $\mathrm{UE}^{22}$. Przykładem jest zaangażowanie sił i środków w ramach cywilno-wojskowej misji EUFOR ALTHEA $^{23}$. Należy podkreślić, że UE przejęła odpowiedzialność za proces stabilizacyjny od NATO inicjując największą operację wojskową w swojej dotychczasowej historii. Polacy znaleźli się w gronie 22 państw członkowskich UE i 11 państw trzecich, które łącznie wystawiły ponad 7 tys. żołnierzy. Polska zdecydowała się wystawić kontyngent na poziomie nieprzekraczającym 300 żołnierzy i pracowników wojska ${ }^{24}$. Z czasem, stabilizacja w BiH pozwoliła na ograniczanie międzynarodowej obecności. W konsekwencji ustaleń, jakie zapadły na forum UE w 2009 roku - podjęto decyzję o zmniejszeniu polskiego udziału do 250 żołnierzy i pracowników wojska ${ }^{25}$. Z początkiem grudnia 2010 roku PKW został zmniejszony do około 50 żołnierzy ${ }^{26}$, tworzących głównie mobilne zespoły szkoleniowe (MTT) ${ }^{27}$. Skala zaangażowania Polski w tę unijną operację przez kolejne lata nie zmieniała się. W listopadzie 2014 roku prezydent Bronisław

Republice Macedonii, MP 2003, nr 16, poz. 229.

22 Należy podkreślić, że najważniejszą formą zaangażowania Polski był udział w operacjach reagowania kryzysowego podejmowanych przez Organizację Paktu Północnoatlantyckiego, zarówno przed przyjęciem Polski do tej organizacji, jak i po (IFOR, SFOR).

23 Zob. J. Barcik, Europejska polityka bezpieczeństwa i obrony. Aspekty prawne i polityczne, Bydgoszcz-Katowice 2008, s. 323-324; J. Zajączkowski, Unia Europejska w stosunkach międzynarodowych, Warszawa 2006, s. 179.

24 Postanowienie Prezydenta Rzeczypospolitej Polskiej z 30.11.2004 roku o użyciu Polskiego Kontyngentu Wojskowego w operacji wojskowej Unii Europejskiej w Republice Bośni i Hercegowiny, MP 2004, nr 51, poz. 863.

25 Postanowienie Prezydenta Rzeczypospolitej Polskiej z 20.11.2009 r. o przedłużeniu okresu użycia Polskiego Kontyngentu Wojskowego w operacji wojskowej Unii Europejskiej w Bośni i Hercegowinie oraz Republice Kosowo i Byłej Jugosłowiańskiej Republice Macedonii, MP 2009, nr 74, poz. 926.

26 Postanowienie Prezydenta Rzeczypospolitej Polskiej z 19.11.2010 r. o przedłużeniu okresu użycia Polskiego Kontyngentu Wojskowego w operacji wojskowej Unii Europejskiej w Bośni i Hercegowinie oraz Republice Kosowo i Byłej Jugosłowiańskiej Republice Macedonii, MP 2010, nr 87, poz. 1016.

${ }^{27}$ http://do.wp.mil.pl/info/pkw-euformtt/ (12.01.2015). 
Komorowski podpisał postanowienie w sprawie przedłużenia okresu uczestnictwa PKW w operacji wojskowej UE w BiH do 12 listopada $2015 \mathrm{roku}^{28}$.

Polska, dążąc do osiągnięcia nakreślonych w polityce zagranicznej celów, angażowała się w prowadzone przez społeczność międzynarodową działania, które miały na celu łagodzenie napięć, przywracanie pokoju, stabilizowanie sytuacji w państwach i regionach objętych konfliktami. Argumentacja polskiego zaangażowania zawsze sprowadzała się do dwóch zasadniczych motywów polskiej obecności - humanitarnego i politycznego. Obszarem szczególnego zainteresowania obok Bałkanów była dla UE Afryka, o czym świadczyło różnorodne instrumentarium skierowane do państw regionu ${ }^{29}$. W odróżnieniu do unijnych operacji prowadzonych na Bałkanach, w Afryce Unia prowadziła operacje samodzielnie. Polska zaangażowała się $\mathrm{w}$ wojskowe operacje UE uczestnicząc w pierwszej wojskowej interwencji przeprowadzanej w ramach reagowania kryzysowego EPBiO, a mianowicie w prowadzonej w Demokratycznej Republice Konga operacji Artemis, a następnie operacji EUFOR w Republice Kongo, operacji EUFOR w Czadzie i Republice Środkowoafrykańskiej ${ }^{30}$. Zaangażowanie Polski motywowano zarówno solidarnością i odpowiedzialnością za pokój i bezpieczeństwo w szerszym globalnym wymiarze, chęcią partycypacji w polityce zewnętrznej UE, jak również realizacją autonomicznych interesów. Włączając się w działania związane z poprawą bezpieczeństwa w Afryce, Polska chciała umocnić swą pozycję w wyznaczaniu europejskiej polityki bezpieczeństwa i obronności. Pozwoliło to budować pozycję Polski zarówno jako wiarygodnego partnera zaangażowanego we wspólną politykę zagraniczną UE ${ }^{31}$, jak i państwa, które solidarnie włącza się w działania na rzecz stabilizacji w odległych geograficznie rejonach. Przykładem jest zaangażowanie Polski w operację EUFOR RD CONGO ${ }^{32}$. Zauważyć należy,

28 Prezydent podpisał postanowienie o przedłużeniu użycia PKW w operacji wojskowej UE w Bośni i Hercegowinie, http://www.bbn.gov.pl/pl/wydarzenia/6091,Prezydent-podpisal-postanowienie-o-przedluzeniu-uzycia-PKW-w-operacji-wojskowej-.html (12.01.2015).

29 Zob. B. Przybylska-Maszner, Od strategii Unii Europejskiej na rzecz Afryki do strategicznego partnerstwa z Afryka - dylematy o realnej wizji wspótpracy, „Przegląd Strategiczny” 2011, nr 1; K. Zajączkowski, Polityka Unii Europejskiej wobec Afryki. Implikacje dla Polski, „Debata” 2011, nr 6, s. 18-25.

30 Zob. M. Musioł, Przeglad interwencji wojskowych i cywilnych UE w Afryce na przyktadzie Demokratycznej Republiki Konga, „Wrocławskie Studia Politologiczne” 2012, nr 13; A. Miller, M. Zieliński, Misja wielonarodowych sit pokojowych w Republice Czadu (EUFOR TCHAD/RCA), Zeszyty Naukowe Akademii Marynarki Wojennej 2008, nr 3.

31 A. Miller, M. Zieliński, Misja..., s. 121, 124.

32 Postanowienie Prezydenta Rzeczypospolitej Polskiej z 27.04.2006 r. o użyciu Polskiego Kontyngentu Wojskowego w operacji Unii Europejskiej w Demokratycznej Republice Konga, MP 2006, poz. 323. 
iż równie istotną przesłanką polskiego zaangażowania była chęć wzmacniania relacji dwustronnych Polski z państwami stanowiącymi trzon inicjowanych misji. Przykładem jest wspomniana operacja EUFOR TCHAD/RCA i oferta wysłania kontyngentu na prośbę Francji żywotnie zainteresowanej rozmieszczeniem w Czadzie i Republice Środkowoafrykańskiej misji wojskowej33.

Podkreślić należy, iż w odróżnieniu od unijnych misji prowadzonych na Bałkanach, Polska nie postrzegała ich w kategoriach strategicznych z punktu widzenia własnych interesów, lecz przez pryzmat europejskiej solidarności, a także - jak zauważono - wzmocnienia relacji dwustronnych. Potwierdzeniem tej filozofii działania był udział polskiego kontyngentu w ramach unijnej operacji szkoleniowo-monitorującej w Mali (EUTM Mali). Należy przypomnieć, iż unijną misję poprzedziła samodzielna interwencja Francji na początku 2013 roku, w celu przywrócenia integralności terytorialnej Mali, rozdartej konfliktem między rządem w Bamako a rebeliantami tuareskimi z północy, a także powstrzymania wzrostu zagrożenia dla regionu Afryki Zachodniej i Północnej oraz samej Europy ze strony islamskich organizacji terrorystycznych ${ }^{34}$. Decyzje związane z wysłaniem samolotu transportowego Herkules C-130 i 50 żołnierzy oraz wsparcie techniczne i logistyczne do Republiki Środkowoafrykańskiej potwierdzały, że Polska nie rezygnuje z udziału w działaniach społeczności międzynarodowej. Wsparcie wysiłków Francji argumentowano tym, że państwo to staje się ważnym partnerem strategicznym Polski ${ }^{35}$. Można zatem uznać, iż interesy polityczne będą w przyszłości istotnym kryterium decydującym o zaangażowaniu sił zbrojnych poza granicami kraju.

Udział w operacjach o wojskowym charakterze nie wyczerpywał zaangażowania Polski w unijne działania. Polska uczestniczyła także w cywilnych operacjach opanowywania kryzysów inicjowanych i organizowanych przez UE. Systematycznie włączała się w przedsięwzięcia z wykorzystaniem zasobów cywilnych, potwierdzając w ten sposób posiadane zdolności, zasoby kadrowe, organizacyjne, rzeczowe, finansowe. Wystarczy przypomnieć misję policyjną UE

33 M. Madej, Polityka bezpieczeństwa Polski, „Rocznik Polskiej Polityki Zagranicznej” 2008, s. 70.

34 K. Rękawek, M. Terlikowski, Wspólna Polityka Bezpieczeństwa i Obrony UE w świetle kryzysu w Mali, Biuletyn PISM 2013, nr 21.

35 Polscy żolnierze jadą na nową misję. Wesprą Francuzów w Rep. Środkowoafrykańskiej, http://m.wiadomosci.gazeta.pl/wiadomosci/1,117915,15168559,Polscy_zolnierze_jada_na_nowa_ misje_Wespra_Francuzow.html (12.01.2015). 
w BiH (EUPM), w której brało udział 12 polskich policjantów ${ }^{36}$. Ich głównym zadaniem było wsparcie działań i doradztwo rozproszonym, niejednolitym i niewyszkolonym służbom porządkowym $\mathrm{BiH}^{37}$.

Polska uczestniczyła również w policyjnej operacji UE Proxima ${ }^{38} .24$ lutego 2004 roku Rada Ministrów zadecydowała o utworzeniu kontyngentu policyjnego i włączeniu go do Misji Policyjnej Unii Europejskiej w FYROM. W operacji tej w ramach prowadzonej misji EUPOL brało udział 3 polskich policjantów ${ }^{39}$. Po wejściu Polski do UE planowano ją wzmocnić. Po upływie przewidzianego mandatem misji okresu funkcjonowania, w połowie grudnia 2005 roku, misja EUPOL Proxima została zakończona i zastąpiona Europejskim Policyjnym Zespołem Doradczym (EUPAT), w którym Polska nie wzięła już udziału.

Polska zaangażowała się również w działania stabilizacyjne UE w Kosowie. W tym przypadku mowa o misji EULEX Kosowo, utworzonej na podstawie dokumentu Rady Unii Europejskiej - Wspólne działanie Rady 2008/124/WPZiB z 4 lutego 2008 roku w sprawie misji Unii Europejskiej w zakresie praworządności w Kosowie, EULEX KOSOWO ${ }^{40}$. Rada Ministrów w grudniu 2008 roku zdecydowała o utworzeniu i skierowaniu do służby na terenie Kosowa Polskiego Kontyngentu Policyjnego Misji Unii Europejskiej EULEX Kosowo ${ }^{41}$.

Z uwagi na zainteresowanie sytuacją we wschodnim sąsiedztwie UE, Polska angażowała się w różnego rodzaju przedsięwzięcia związane z bezpieczeństwem wschodnich rubieży UE. Stąd obecność polskich ekspertów w misji granicznej EU BAM - Ukraina i Mołdawia ${ }^{42}$. Polska jest aktywnie zaangażowana w Misję

36 Warunki naszego udziału, w tym charakter kosztów, jakie ponosiła polska strona, określała Umowa między Rzecząpospolitą Polską a Unią Europejską w sprawie uczestnictwa Rzeczypospolitej Polskiej w Misji Policyjnej Unii Europejskiej (EUMP) w Bośni i Hercegowinie (Bośni i Hercegowiny), MP 2004, nr 36, poz. 641.

37 Zob. J. Barcik, Europejska polityka bezpieczeństwa..., s. 312-331; Decyzja Rady 2011/781/WPZiB z 1.12.2011 r. w sprawie Misji Policyjnej Unii Europejskiej (EUMP) w Bośni i Hercegowinie (BiH), Dz. Urz. WE L. 319/51; Działalność polskich kontyngentów policyjnych, http://www.info.policja.pl/portal/inf/871/47732/Misje_pokojowe_informacje_ogolne.html (20.01.2013).

38 Wspólne Działanie Rady 2003/681/WPZiB z 29.09.2003 r. w sprawie Misji Policyjnej Unii Europejskiej w Byłej Jugosłowiańskiej Republice Macedonii (EUPOL Proxima), Dz. Urz. UE L. 249/66.

39 J. Barcik, Europejska polityka bezpieczeństwa..., s. 310-311.

40 Dz. Urz. UE L. 42/92, 16.02.2008.

${ }^{41}$ Wcześniej polscy policjanci wypełniali zadania w ramach Tymczasowej Misji Administracyjnej UNMIK w Kosowie. Każdorazowo w polskim kontyngencie policyjnym służyło 115 funkcjonariuszy oraz grupy ekspertów.

42 Wspólna Deklaracja Centralnego Biura Śledczego i EUBAM, http://www.policja.pl/ pol/aktualnosci/77175, dok.html (12.02.2015). 
Obserwacyjną Unii Europejskiej w Gruzji i stara się utrzymywać w niej liczbę personelu na stałym poziomie 25 osób. Wśród nich są eksperci z Ministerstwa Obrony Narodowej, Ministerstwa Spraw Zagranicznych, policjanci oraz osoby zatrudnione na kontrakcie w ramach misji ${ }^{43}$.

Polska zaangażowała również swój potencjał do części realizowanych przez UE misji cywilnych poza Europą. Przykładem jest ustanowiona w ramach ESDP w czerwcu 2007 roku misja policyjna w Afganistanie. Polski wkład personalny w misję to 3 policjantów ${ }^{44}$.

\section{Pomiędzy idealizmem a realizmem - wyzwania w kontekście udziału Polski w operacjach pokojowych UE}

W nowej pozimnowojennej rzeczywistości udział Polski w operacjach pokojowych miał spełniać kilka funkcji: po pierwsze, integrującą Polskę ze społecznością międzynarodową; po drugie, adaptacyjną, a więc przystosowującą Polskę do środowiska międzynarodowego i oddziałującą na to środowisko; po trzecie, ochronną, związaną z zagwarantowaniem bezpieczeństwa. Po czwarte, wspierającą realizację priorytetów w polityce zagranicznej.

Dziś o stopniu zaangażowania w operacje pokojowe w coraz większym stopniu przesądza realizm polityczny. Obecne są wprawdzie akcenty idealistyczne, bowiem motyw solidarności, odpowiedzialności, wiarygodności wciąż jest żywy. Następuje jednak swoiste „realistyczne przebudzenie”. Wydawać by się mogło, że tak właśnie należy odczytywać deklaracje prezydenta Bronisława Komorowskiego z sierpnia 2013 roku o końcu polityki ekspedycyjnej, jego zdaniem nieopatrznie ogłoszonej w 2007 roku, czyli miał to być koniec łatwego wysyłania żołnierzy na antypody świata. Celem nadrzędnym ma być obrona własnego terytorium, a zaangażowanie w misje - racjonalne. Nadal dbając o wiarygodność i solidarność sojuszniczą, deklarowano udział w misjach, ale w misjach na miarę potrzeb i możliwości. Można zatem sądzić, iż dotychczas prowadzone działania Polski były ponad miarę i możliwości państwa średniej rangi. Można też przypuszczać, iż nie zawsze racjonalnie kalkulowano potencjalne korzyści i koszty związane z polską aktywnością. Trudno jednak sobie wyobrazić sytuację, w której Polska skoncentruje się tylko i wyłącznie na obronie własnego terytorium.

43 A. Ciupiński, Wspólna..., s. 328-336.

44 EUPOL w Afganistanie, http://www.info.policja.pl/inf/wspolpraca-miedzynarod/misje -pokojowe/55334,EUPOL-w-Afganistanie.html (12.02.2015). 
Konfliktogenność, która towarzyszy współcześnie stosunkom międzynarodowym, wyklucza taką formę izolacjonizmu.

Polskę bezsprzecznie należy postrzegać jako państwo, które aktywnie uczestniczy w działaniach na rzecz bezpieczeństwa międzynarodowego angażując się politycznie i militarnie we wszelkich przedsięwzięciach społeczności międzynarodowej. Jedynymi ograniczeniami były i są czynniki ekonomiczne, decydujące o możliwościach kadrowych i organizacyjnych. Stąd polityczne decyzje o skoncentrowaniu aktywności w ramach operacji pokojowych na tych realizowanych w pierwszej kolejności przez NATO i UE. Oscylując pomiędzy partkularyzmem a solidaryzmem, angażując się w działania społeczności międzynarodowej, usiłowano z jednej strony wspierać realizację zasadniczych priorytetów w polityce zagranicznej, z drugiej zaś, powołując się na solidaryzm, współuczestniczyć w rozwiązywaniu problemów nękających społeczność międzynarodową.

Polska angażuje się w część unijnych przedsięwzięć o wojskowym i cywilnym charakterze, uzależniając skalę i charakter swego uczestnictwa od zdefiniowanych interesów narodowych. Warto również podkreślić, iż Polska nie jest organizatorem działania innych państw UE, jest natomiast partnerem w wielu prowadzonych operacjach. Posiadane zdolności kadrowe i finansowe obligują Polskę do ukierunkowania swej aktywności na te misje, które z punktu widzenia polskiej racji stanu mają wymiar strategiczny. Do takich z całą pewnością należą misje UE, w szczególności te prowadzone w regionach istotnych z punktu widzenia założeń realizowanej polityki zagranicznej.

Polska brała natomiast udział w misjach prowadzonych w ramach WPBiO, demonstrując w ten sposób solidarność z innymi państwami. Jak zauważa Jacek Czaputowicz, Polska przestała być jedynie konsumentem bezpieczeństwa, a stała się jego producentem. Będąc szóstym co do wielkości krajem Unii Europejskiej, jest na piątym miejscu pod względem udziału w unijnych operacjach ${ }^{45}$. Polska jest akceptowana jako partner wojskowy, a jej zaangażowanie w operacje zagraniczne jest powszechnie uznane ${ }^{46}$. Jako europejski sojusznik jest zobowiązana do wnoszenia wkładu w umacnianie bezpieczeństwa w wymiarze regionalnym i globalnym. Niezależnie od ograniczeń towarzyszących owemu zaangażowaniu, jest to znaczący instrument realizowania zarówno interesów wspólnotowych, jak i narodowych. Jednakowoż rozwagi wymaga charakter uczestnictwa uwzględniający z jednej strony „potrzeby” społeczności międzynarodowej, z drugiej zaś własne możliwości.

45 J. Czaputowicz, Polityka bezpieczeństwa Polski..., s. 31.

46 Ibidem, s. 35. 


\section{Konkluzje}

Udział w operacjach pokojowych i misjach stabilizacyjnych jest jednym z istotnych zadań, jakie stawia sobie współcześnie Polska. Pomimo zmiany filozofii udziału w operacjach pokojowych jest to wciąż zasadnicza forma zaangażowania Polski w rozwiązywanie problemów globalnych i regionalnych, a przede wszystkim forma aktywnego uczestnictwa w działaniach UE na rzecz utrzymania pokoju, zapobiegania konfliktom oraz wzmacniania międzynarodowego bezpieczeństwa. Niezależnie od modyfikacji charakteru zaangażowania Polski w działania społeczności międzynarodowej, udział w operacjach pokojowych UE pozostaje istotnym, aczkolwiek jednym z wielu instrumentów realizacji polityki zagranicznej.

\section{Bibliografia}

Balcerowicz Bolesław, Aktywność Polski $w$ dziedzinie bezpieczeństwa euroatlantyckiego, w: Polityka zagraniczna Polski po wstapieniu do NATO i Unii Europejskiej, red. Stanisław Bieleń, Warszawa 2010.

Barcik Jacek, Europejska polityka bezpieczeństwa i obrony. Aspekty prawne i polityczne, Bydgoszcz-Katowice 2008.

Ciupiński Andrzej, Wspólna Polityka Bezpieczeństwa i Obrony Unii Europejskiej. Geneza. Rozwój. Funkcjonowanie, Warszawa 2013.

Czaputowicz Jacek, Polityka bezpieczeństwa Polski - między samodzielnościa a europeizacja, ,e-Politikon”, nr 4.

Drzewicki Andrzej, Strategia udziału Sił Zbrojnych Rzeczypospolitej Polskiej w operacjach międzynarodowych. Aspekty polityczne i wojskowe, „Rocznik Bezpieczeństwa Międzynarodowego" 2011, vol. 5.

Kozerawski Dariusz, Kontyngenty Wojska Polskiego w międzynarodowych operacjach pokojowych w latach 1973-1999. Konflikty - interwencja-bezpieczeństwo, Toruń 2012.

Kulesa Łukasz, Operacje Unii Europejskiej w ramach europejskiej polityki bezpieczeństwa i obrony, Biuletyn PISM 2004, nr 42.

Łoś-Nowak Teresa, Wspólna Polityka Zagraniczna i Bezpieczeństwa Unii Europejskiej z perspektywy Polski, „Przegląd Europejski” 2005, nr 1.

Madej Marek, Polityka bezpieczeństwa Polski, „Rocznik Polskiej Polityki Zagranicznej” 2008. 
Miller Anna, Zieliński M., Misja wielonarodowych sit pokojowych $w$ Republice Czadu (EUFOR TCHAD/RCA), Zeszyty Naukowe Akademii Marynarki Wojennej 2008, nr 3.

Musioł Marek, Przeglad interwencji wojskowych i cywilnych UE w Afryce na przykładzie Demokratycznej Republiki Konga, „Wrocławskie Studia Politologiczne” 2012, nr 13 .

Pawłowski Konrad, Misje pokojowe $i$ operacje stabilizacyjne Sit Zbrojnych Rzeczypospolitej Polskiej na początku XXI wieku: przesłanki i głosy krytyczne, http://www.pan-ol.lublin.pl/wydawnictwa/TPol5/Pawlowski.pdf.

Posel-Częścik Edyta, Współpraca NATO i Unii Europejskiej w dziedzinie opanowywania kryzysów, Biuletyn PISM 2004, nr 39.

Przybylska-Maszner Beata, Od strategii Unii Europejskiej na rzecz Afryki do strategicznego partnerstwa z Afryka - dylematy o realnej wizji wspótpracy, „Przegląd Strategiczny" 2011, nr 1.

Rękawek Kacper, Terlikowski Marcin, Wspólna Polityka Bezpieczeństwa i Obrony UE w świetle kryzysu w Mali, Biuletyn PISM 2013, nr 21.

Stemplowski Ryszard, Wprowadzenie do analizy polityki zagranicznej, wyd. II rozsz., t. II, Warszawa 2007.

Woźnica Rafał, Rola Unii Europejskiej w realizacji postanowień porozumienia ochrydzkiego dotyczacego policji, w: Tożsamość narodowa $w$ społeczeństwie multietnicznym, red. Maciej Kawka, Irena Stawowy-Kawka, Kraków 2008.

Wójtowicz Joanna, Specyfika Wspólnej Polityki Zagranicznej i Bezpieczeństwa w świetle postanowień Traktatu z Lizbony - instrumenty i ramy prawno-instytucjonalne, „Studia i Analizy Europejskie” 2011, nr 2.

Zajączkowski Jakub, Unia Europejska w stosunkach międzynarodowych, Warszawa 2006.

Zajączkowski Kamil, Polityka Unii Europejskiej wobec Afryki. Implikacje dla Polski, „Debata” 2011, nr 6.

Zięba Ryszard, Polska we Wspólnej Polityce Bezpieczeństwa i Obrony Unii Europejskiej, „Polityka i Społeczeństwo” 2012, nr 10.

Zięba Ryszard, Unia Europejska, w: Międzynarodowe stosunki polityczne, red. Marek Pietraś, Lublin 2006.

Zięba Ryszard, Wspólna Polityka Zagraniczna i Bezpieczeństwa Unii Europejskiej, Warszawa 2005.

Zięba Ryszard, Z Waszyngtonem czy Bruksela - dylemat polskiej polityki bezpieczeństwa, w: Unia Europejska i Polska wobec dylematów integracyjnych na poczatku XXI wieku, red. Mieczysław Stolarczyk, Toruń 2006. 


\title{
Streszczenie
}

Jedynym z istotnych fragmentów realizowanej po 1989 roku polityki zagranicznej jest zaangażowanie Polski w działania społeczności międzynarodowej na rzecz umacniania bezpieczeństwa w państwach i regionach konfliktogennych. Polska konsekwentnie wykorzystuje udział w operacjach pokojowych prowadzonych pod auspicjami organizacji międzynarodowych i koalicji ad hoc jako instrument realizacji polityki zagranicznej. Celem artykułu jest analiza motywów i skali zaangażowania Polski w operacje pokojowe UE z perspektywy polityki zagranicznej po 1989 roku. Przyjęta konstrukcja artykułu nie pozwala na wieloaspektową analizę a jedynie na skoncentrowanie się na wybranych kwestiach, a mianowicie motywach i dylematach zaangażowania Polski w operacje pokojowe UE.

Słowa kluczowe: polska polityka zagraniczna, Unia Europejska, operacje pokojowe

\section{POLISH PARTICIPATION IN PEACEKEEPING OPERATIONS OF THE EUROPEAN UNION. DILEMMAS AND CHALLENGES}

\begin{abstract}
Summary
One of the significant elements of the foreign policy pursued after 1989 is Poland's engagement in the activities of the international community for strengthening the security in conflict-prone states and regions. Poland has consequently utilised the participation in peacekeeping operations, carried out under the auspices of international organisations and coalitions created $a d h o c$, as an instrument for implementing its foreign policy. The aim of the article is the analysis of the character, scale and motives for Poland's involvement in the peacekeeping operations of the European Union, from the perspective of the foreign policy after 1989. The adopted construction of the article does not allow to conduct a multi-faceted analysis, but only to concentrate on selected issues, namely the motives and dilemmas of Polish engagement in the European Union's peacekeeping operations.
\end{abstract}

Keywords: polish foreign policy, European Union, peacekeeping operations 
